\title{
Physical Properties of Soils Affected by the Use of Agricultural Waste
}

\author{
María Belén Almendro-Candel, \\ Ignacio Gómez Lucas, Jose Navarro-Pedreño and \\ Antonis A. Zorpas \\ Additional information is available at the end of the chapter \\ http://dx.doi.org/10.5772/intechopen.77993
}

\begin{abstract}
This chapter provided an overview of the physical properties of soils and their importance on the mobility of water and nutrients and the development of a vegetation cover. It also gives some examples of why the use of agricultural residues can affect positively soil physical properties. The incorporation of agricultural wastes can be a sustainable practice to improve soil characteristics, favoring a model of zero waste in agricultural production and allowing better management of soils. We review and analyze the effect of the use as amendments of different agricultural residues, on physical properties of the soil (e.g., bulk density, porosity, and saturated hydraulic conductivity), especially related to the movement of water in the soil.
\end{abstract}

Keywords: saturated hydraulic conductivity, bulk density, porosity, agricultural wastes

\section{Introduction}

The major environmental problems all over the world are the production and accumulation of wastes. Many considerations should be taken into account but, especially, those from the targets given by the European Union (EU). These problems related to wastes, together with the exhaustion of many resources, direct the European Union (EU) toward a strategy of zero waste through the circular economy. The transition to a more circular economy, where the value of products, materials, and resources is maintained in the economy for as long as possible, and the generation of waste minimized is an essential contribution to the EU's efforts to develop a sustainable, low-carbon, resource-efficient, and competitive economy [1]. 
In the EU plan action for the circular economy, we can find targeted actions for various types of waste. Agricultural wastes can be reflected in two aspects of this plan: recycling of nutrients and biomaterials.

Recycled nutrients are a distinct and important category of secondary raw materials, for which the development of quality standards is necessary. They are present in organic waste and can be returned to soils as fertilizers. Their sustainable use in agriculture reduces the need for mineral-based fertilizers, the production of which has negative environmental impacts, and depends on imports, e.g., phosphate rock, a limited resource [1].

Bio-based materials, e.g., those based on biological resources (such as wood, crops, or fibers), can be used for a wide range of products (construction, furniture, paper, food, textile, chemicals, etc.) and energy uses (e.g., biofuels). The bioeconomy hence provides alternatives to fossil-based products and energy and can contribute to the circular economy. Bio-based materials can also present advantages linked to their renewability, biodegradability, or compostability. On the other hand, using biological resources requires attention to their life cycle environmental impacts and sustainable sourcing. The multiple possibilities for their use can also generate competition for them and create pressure on land use [1].

Agriculture is one of the major activities that produces wastes and consumes space, the agricultural soils. It is important to find a synergy between this activity and the soil. In this sense and following the considerations of the EU, crop residues are an important source of plant nutrients and organic matter [2]. Reuse of organic materials is desirable in order to reduce waste streams and to take advantage of the soil benefits associated with added organic matter and associated plant nutrients [3].

Nowadays, it is well known that the application to the soil of organic amendments derived from urban, agricultural, industrial, or municipal activity has several agronomic and environmental effects [4]. This addition can be a good strategy to maintain or even increase the levels of organic carbon in the soil [5]; to improve physical properties such as stability of aggregates and soil porosity [6-8]; to incorporate nutrients such as N, P, and K, thus avoiding the high fossil energy costs and therefore the impact on global warming due to the production and the use of synthetic fertilizers [9]; and to help cushion climate change through the sequestration of atmospheric $\mathrm{CO}_{2}$ by the organic compounds of the soil [10].

Considering the physical properties and the soil organic carbon (SOC), organic matter amendments can increase water holding capacity, soil porosity, water infiltration, and percolation while decreasing soil crusting and bulk density [11-13]. One of the main measurable effects of the repeated application in the soil of organic wastes is the increase of soil porosity and, therefore, the decrease in the bulk density of the soil $[8,14]$. It is also expected to be beneficial for the work of tilling the soil, thus reducing the draft force and, consequently, a possible decrease in tractor fuel [15]. The energy saved due to the lower resistance that the soil offers when being worked if we apply waste is being ignored from the waste treatments that imply the application to the soil of this in the environmental evaluations. However, reducing greenhouse gas emissions can be important [15]. 
This chapter pays attention to the physical properties of the soil due to their importance in plant growth and soil stability and the possibilities associated to the use of agricultural wastes. Moreover, it is centered in applying the circular economy concept and zero waste in agricultural systems that can be able to reuse their own wastes.

Agricultural wastes can be used as a source of organic matter and nutrients for soils and influence the physical properties of soils. They can also be easily applied as mulching, providing numerous advantages [16]. So, this chapter gives an overview of the positive effects of recycling vegetable wastes and soil physical properties.

\section{Importance of the physical properties of the soil}

The physical properties of the soil are very important for agricultural production and the sustainable use of soil. The amount and rate of water, oxygen, and nutrient absorption by plants depend on the ability of the roots to absorb the soil solution as well as the ability of the soil to supply it to the roots. Some soil properties, such as low hydraulic conductivity, can limit the free supply of water and oxygen to the roots and affect negatively to the agricultural yield.

\subsection{Soil structure}

Soil structure is one of the most important soil's physical factors controlling or modulating the flow and retention of water, solutes, gases, and biota in agricultural and natural ecosystems [17, 18]. Soil structure is very important in soil productivity and is a limiting factor of crop yield [19, 20]. Soil structure controls many processes in soils. It regulates water retention and infiltration, gaseous exchanges, soil organic matter (SOM) and nutrient dynamics, root penetration, and susceptibility to erosion [21]. For these reasons, soil structure stands out among the physical properties of the soil, since it exerts an important influence on the edaphic conditions and the environment.

The term "structure" of a granular medium refers to the spatial arrangement of solid particles (texture) and void spaces. Most soils tend to exhibit a hierarchical structure. That is, primary mineral particles, usually in association with organic materials, form small clusters or "firstorder aggregates." These form larger clusters or "second-order aggregates" [22]. Aggregate hierarchy in soils is reflected in increasing aggregate size with each successive level. However, the term "structure" in soil cience generally carries a connotation of bonding mechanisms in addition to geometrical configuration of particles [22]. Organic matter acts as a cement that can help the formation of aggregates and, therefore, the soil structure.

Without hierarchical structure, medium- and fine-textured soils such as loams and clays would be nearly impermeable to fluids and gases [22]. Moreover, the soil organic carbon has a greater effect on aggregation especially in coarse-textured soils [23]. Thus, structure plays a crucial role in the transport of water, gases, and solutes in the environment and in transforming soil into a suitable growth medium for plants and other biological organisms [22]. 
Aggregation is an indicator of soil structure and results from the rearrangement of particles, flocculation, and cementation [24-26]. Organic matter has been clearly identified as one of the key components of soil structural stability. However, in agricultural soils, it is progressively being depleted by intensive cultivation, without adequate yield of plant biomass. The loss of soil structure is increasingly seen as a form of soil degradation [27] and is related to the activities that are carried out in the soil and by the crop. Maintenance of optimum soil physical conditions is important for sustaining plant growth and other living organisms in soils. Poor soil structure results in poor water and aeration conditions that restrict root growth, thus limiting efficient utilization of nutrients and water by plants [28]. Soil structure also determines the depth that roots can penetrate into the soil [29].

\subsection{Aggregate stability}

Soils with high organic matter content tend to have larger, stronger, and more stable aggregates that resist compaction, whereas the opposite is true for soils with less organic matter. An improvement in soil aggregate stability has several consequences for an agroecosystem, including reduced risk of soil compaction and erosion [30]. The quality of soil structure greatly depends on the soil organic carbon (SOC) content [31], especially on the fraction of labile SOC (also called the "particulate organic matter" because of this fraction cycles relatively quickly in the soil). Labile organic matter also plays an important role in maintaining soil structure and providing soil nutrients [32].

Aggregate stability is a keystone factor in questions of soil physical fertility and can be enhanced by means of an appropriate management of organic amendments, which can maintain an appropriate soil structure. This agronomic procedure could improve pore space suitable for gas exchange, water retention, root growth, and microbial activity [9]. Aggregate stability at the soil surface is affected mainly by exposure to rainfall (drop impact and runoff). A bare soil (e.g., a soil from which crop residues have been exported or incorporated into the soil by plowing) is in direct contact with raindrops, which facilitates a breakdown of soil aggregates, increasing soil erodibility. Aggregate degradation can lead to surface sealing and crust formation, which reduces the water infiltration rate and increases the risk of soil erosion and the loss of valuable topsoil [33]. High silt content, together with low organic matter content, results in soils that are more prone to aggregate breakdown and surface crusting [29, 34]. Organic matter applied on the topsoil protects to the erosion and favors the aggregation of mineral particles.

\subsection{Soil compaction}

Soil compaction is a form of physical degradation in which soil biological activity and soil productivity for agricultural and forest cropping are reduced, resulting in environmental consequences. Compaction is a process of densification and distortion in which total and airfilled porosity and permeability are reduced, strength is increased, soil structure are partly destroyed, and many changes are induced in the soil fabric and in various characteristics [35].

Generally, four indicators quantify soil compaction: total porosity, pore size distribution, bulk density, and penetration resistance. Given that root growth is impeded by soil compaction, 
these indicators are probably negatively correlated with root growth and rooting depth [29]. Even more, these properties are closely related to water movement, water availability for plants, and soil gas exchange.

\subsection{Porosity}

Porosity is a main indicator of soil structural quality. Therefore, its characterization is essential for assessing the impact of adding organic matter to a soil system. Reduced porosity results from the loss of larger pores and the increase of finer pores [36].

A soil's porosity and pore size distribution characterize the pore space of the portion of the soil's volume that is not occupied by solid material. The basic character of the pore space governs critical aspects of almost everything that occurs in the soil: the movement of water, air, and other fluids; the transport and the reaction of chemicals; and the residence of roots and other biotas. By convention, the definition of pore space excludes fluid pockets that are totally enclosed within solid material. Thus, porous space is considered a single and a continuous space within the body of soil. In general, it has fluid pathways that are tortuous, variably constricted, and usually highly connected among themselves [37].

The relationship between the storage capacity and the movement of water in soils with porosity is evident and fundamental. However, not only the total number of pores defines the water behavior of the soil but also and in many cases predominantly the shape, size, and distribution of the pores. From the agronomic point of view, the size distribution not only affects the amount of water that can hold the soil but also regulates the energy with which it is retained, the movement toward the plant, toward the atmosphere, and toward other zones of soil.

The use of agricultural wastes as soil amendments facilitates the maintenance of the porosity in two forms: directly, if the agricultural wastes are ligneous matters with high resistance to biodegradation and, indirectly, after the transformation of the initial organic matter into humic substances and forming aggregates and enhancing the soil structure.

\subsection{Bulk density}

One of the most prominent indicators of soil structure is soil bulk density (dry bulk density (BD)), its determination does not require any specific expertise or expensive equipment, and it is based on sampling undisturbed soil. Bulk density (BD) is calculated as the ratio of the dry mass of solids to soil volume. The values of both bulk and particle density are necessary to calculate soil porosity [38]. Porosity can then be derived from BD, knowing or approximating the particle density value [21].

This physical property is dynamic and varies depending on the edaphic structural conditions. It can also be modified by soil biota, vegetation, and mechanical practices, trampling by livestock, agricultural machinery, weather and season of the year, etc. [39, 40].

Bulk density is an important indicator of soil quality, productivity, compaction, and porosity. $\mathrm{BD}$ is mainly considered to be useful to estimate soil compaction. Root length density, root 
diameter, and root mass were observed to decrease after an increase in BD [41]. However, the interpretation of $\mathrm{BD}$ with respect to soil functions depends on soil type, especially soil texture and soil organic matter (SOM) content [21].

\subsection{Hydraulic conductivity}

One of the properties most directly related to the structure and movement of water in the soil is hydraulic conductivity. It is known that water movement in soils occurs both vertically and horizontally, depending on the humidity conditions. In saturated conditions, which occur below the groundwater level, the movement is predominantly horizontal and in a lesser proportion in a vertical direction. In conditions of non-saturation, when the large pores are filled with air, the flow is preferably vertical. The ability of soil to transmit water depends on the presence of interlinked pores and their size and geometry [42].

The saturated hydraulic conductivity (Ksat) of soil is a function of soil texture, soil particle packing, clay content, organic matter content, soil aggregation, bioturbation, shrink-swelling, and overall soil structure [43-46]. The Ksat is one of the main physical properties that aids in predicting complex water movement and retention pathways through the soil profile [47, 48], and it is also widely used as a metric of soil physical quality [49].

\subsection{Water holding capacity}

Water holding capacity is the ability of a soil to storage water. Thus, the importance of this storage is that water can be available for plants. Environmental conditions such rain, temperature, and isolation join to the soil properties of soil organic matter, texture, and structure and determine the capacity of a soil to retain water.

In rainfed agriculture of arid and semiarid environments, the capacity of the soil to store water plays an important role in the success of crops. Infiltration and evaporation are the most important processes that determine the storage of water in the soil. Surface conditions play an important role in determining the infiltration and evaporation rates of water in the soil. Tillage is the most effective way to modify the characteristics of the soil surface due to its effect on the porous space (shape, volume, and continuity of the pores).

The roughness of the soil surface is another property of the soil that influences the balance of water, since it increases the storage capacity in soil depressions [50, 51]. In agricultural soils, the roughness of the surface is influenced by tillage, vegetation, soil type, and rainfall intensity [51].

The use of waste as surface cover has been shown to be effective in reducing the evaporation of water from bare soil, which translates into a greater potential availability of water for plants [16]. This reduction is due to the isolation of the soil from the sun's rays and the temperature of the air and the increase in the resistance to the flow of water vapor by reducing the wind speed $[52,53]$.

However, it is also necessary to determine the influence on the movement of water in the soil profile. In the arable layer, it is determinant for the proper functioning of agricultural soils. Therefore, the determination of hydraulic conductivity becomes very relevant information to predict the proper behavior of water against infiltration and storage capacity or loss by the soil. 


\section{The use of agricultural wastes in soils}

Agricultural residues used as soil amendments or fertilizers may represent an excellent recycling strategy [54]. They are important to improve soil physical (e.g., structure, infiltration rate, plant available water capacity), chemical (e.g., nutrient cycling, cation exchange capacity, soil reaction), and biological (e.g., SOC sequestration, microbial biomass $\mathrm{C}$, activity, and species diversity of soil biota) properties as organic soil conditioners [55-58]. Cultivating crops that produce substantial amounts of residues can increase SOC in the soil profile, depending on the tillage practices used [29]. Incorporated residue can beneficially influence soil chemical and physical properties, especially in non-flooded soils [57].

Organic residues can contribute to the development of soil structure with a binding agent in the formation of aggregates. The application of organic wastes to soils reduces bulk density; increases total pore space, mineralization, available nutrient elements, and electrical conductivity of soils; and increase microbial activity [26, 59, 60].

Crop residue application offers several environmental and ecological benefits for the soilwater-plant system, including improved soil structural quality, which ensures optimum soil functions. Generally, the incorporation of crop residues increases soil porosity (especially the large pores) and reduces soil bulk density, regardless of tillage operations. Large pores are particularly favored because organic matter is much less dense than mineral particles. The application rate can affect the extent of compaction. The effect of crop residues in a given tillage practice also depends on soil type and depth. When they are mechanically incorporated, crop residues can reduce the bulk density at depth. Conservation tillage with the incorporation of crop residues increases SOC content near the soil surface, whereas in conventional tillage, soil $C$ is distributed throughout the plowed area. Soils with higher organic matter content tend to have higher aggregate stability and therefore less risk of compaction and soil erosion [29].

With regard to soil hydraulic properties, the presence of crop residues on the soil surface tends to increase hydraulic conductivity at the surface, whereas tillage affects soil hydraulic properties both at the soil surface and below it because of the destabilization of soil aggregates [61]. The influence of residue management on crop production is complex and variable and results from direct and indirect effects and interactions. A direct effect is, for example, the presence of residues on the soil surface, which constitutes a direct obstacle to crop emergence. Indirect effects include residue mineralization, which leads to more nutrients available for the plants or the presence of organic matter from residues modifying the soil structure and therefore modifying the root system development [29].

Incorporation of vegetable crop residues affects soil quality not only in terms of nutrient supply but also by influencing soil food web organisms and improving soil physicochemical properties, resulting in a better environment for crop growth and improved productivity [62-69]. The application of organic residues on carbon and nitrogen mineralization and biochemical properties in an agricultural soil led to a significant increase in soil microbial biomass size and activity [54].

Poppy waste, a suitable seed-free, inexpensive source of non-animal-based organic carbon, was used to evaluate its effect on soil organic carbon content and production of Bocane spinach 
(Spinacia oleracea) [70]. Application of poppy waste at $200 \mathrm{~m}^{3} /$ ha increased soil organic carbon content, soil $\mathrm{pH}$, and soil salinity.

Wheat stalk, cotton stalk, millet stalk, and soybean stalk were used as the main material, and oven-dried lentil straw was used as an additive material in 100:10, 100:15, and 100:20 w:w ratios for $100 \mathrm{~g}$ of main material (70\% moisture content) to cultivate Pleurotus ostreatus and try to improve the total harvest amount [71].

\subsection{Composted agricultural wastes}

Agricultural wastes can be composted before their application to soil. The composting process, with other residues or alone, facilitates the transformation into a stable organic matter, more complex and more resistant to the biodegradation. However, the control of the process should be undertaken in order to obtain a mature compost [72]. Green tea waste and rice bran were composted, while various parameters such as compost pile temperature, $\mathrm{pH}$, electrical conductivity, nitrate content, and carbon to nitrogen ratio were measured regularly. There was no further change in the state of the compost pile after 90 days indicating that it could be used for agricultural applications [73]. The possible bioconversion of wet olive cake by low-cost biostabilization (vermicomposting process) has been evaluated [74]. Wet olive cake fresh (WOC), pre-composted (WOCP), or mixed with biosolids (WOCB) were vermicomposted for 6 months to obtain organic amendments for agricultural and remediation purposes.

The application of composted organic amendments derived from different crop residues, generally, has a positive impact on the physical, chemical, and biological properties of soils [75].

Crop residues are composed of lignin, cellulose, hemicellulose, micro-, and macronutrients. The degradation of these residues varies depending not only on their lignin and cellulose content and their $\mathrm{C} / \mathrm{N}$ ratio, which is crop dependent, but also on the environment and soil conditions. Residues with a high C/N level (e.g., wheat straw) decompose slowly, sometimes resulting in the immobilization of soil $\mathrm{N}$. This can be positive in no-tillage systems, creating a mulch that protects the soil from erosion and evaporation, but it also means that there are fewer nutrients available for the next crop. Residues with a low $\mathrm{C} / \mathrm{N}$ level mineralize quickly, releasing more $\mathrm{N}$ and nutrients for the next crop. Only specialized fungi and some microorganisms can degrade lignin. Residues with high lignin content will take longer to decompose than those with low lignin content $[29,76]$.

\section{Examples of the use of agricultural wastes and the effects on some physical properties}

The physical properties of soils condition their quality and, in particular, the porosity which affects different processes related to the transformations of organic matter, gas exchange, the growth of plant roots, and movement of water in the soil, as before it was indicated. 
Soil porosity is the property that, due to the effect of compaction, is being altered largely in the European Union (and developing countries), together with the loss of organic matter from soils [77], and, for this reason, our management of the soils should allow maintaining this property at adequate levels.

The use of plant residues as soil amendments is a sustainable alternative to improve the physical properties [28], although we must take into account the characteristics of the waste to ensure its efficiency. Once incorporated into the soil, the waste can be mineralized more or less rapidly, depending on characteristics such as its degree of lignification, its $\mathrm{C} / \mathrm{N}$ ratio, and environmental conditions [78]. Fresh vegetable residues, such as tomato $(\mathrm{C} / \mathrm{N}=12)$ and onion $(\mathrm{C} / \mathrm{N}=15)$ residues [79], with high water content, decompose quickly [80] modifying the composition of soil organic matter [9]. However, there are residues with high $\mathrm{C} / \mathrm{N}$ ratios, such as wheat or rice wastes $(\mathrm{C} / \mathrm{N}=105)$, more lignified, which degrade more slowly [81], lasting for more time the modifications they produce on certain physical properties of the soil.

In this second type of waste, we can consider the cereal straw and the palm tree leaves (Figure 1). Both, with high lignin composition and after a conditioning process (drying and crushing), can be used to modify the physical properties of the soil such as bulk density, porosity, and hydraulic conductivity.

These agricultural wastes have a similar total organic matter (determined by loss on ignition) content but a different density, bulk, and particle density (Table 1).

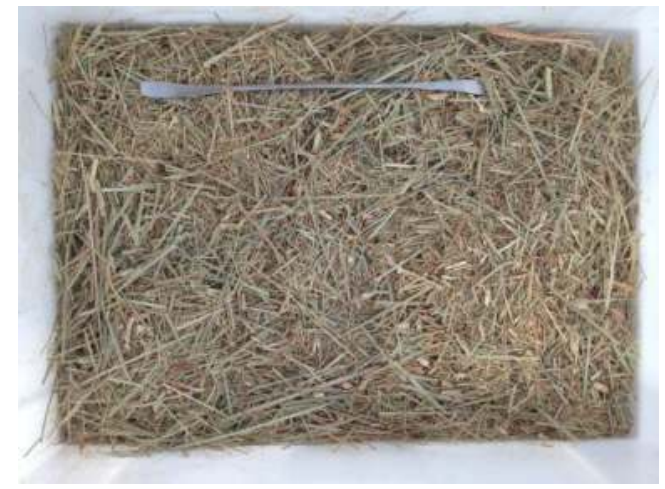

Figure 1. Palm tree leaves.

\begin{tabular}{lll}
\hline & Palm tree leaves & Hay straw \\
\hline Bulk density $\left(\mathrm{kg} / \mathrm{m}^{3}\right)$ & 84 & 29 \\
Particle density $\left(\mathrm{kg} / \mathrm{m}^{3}\right)$ & 870 & 405 \\
Organic matter $(\%)$ & 93.2 & 94.8 \\
\hline
\end{tabular}

Table 1. Density and total organic matter in the wastes. 
Laboratory experiments were performed on cylinders similar to those used for the determination of densities of organic materials, according to UNE-EN13040:2008 and the methods of soil analysis of SSSA-ASA [82-84]. These experiments showed that the agricultural residues applied (hay straw and palm tree leaves, air dry and cut with a size of approximately $4 \mathrm{~cm}$ in length) modified the density of soils and improved their porosity.

Figures 2 and 3 show the changes of the particle (PD) and bulk (BD) densities in two soils (soil 1: sandy clay loam; soil 2: clay loam), when these wastes were added in a proportion (waste/ dry soil): 0,3 , and $6 \%(\mathrm{w} / \mathrm{w})$.

The agricultural residues reduced the densities of the two soils, depending on the dose applied. The apparent densities were clearly affected, which indicates that the addition of the amendments favors that the soils were less compacted. Depending on the physical characteristics of

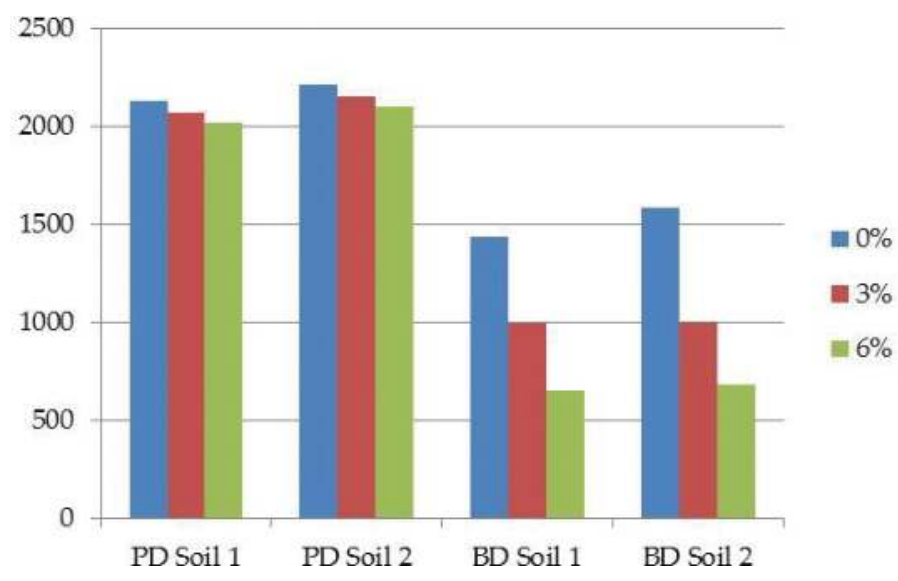

Figure 2. Evolution of particle density (PD) and bulk density (BD) (in $\left.\mathrm{kg} / \mathrm{m}^{3}\right)$ in soils amended with hay straw.

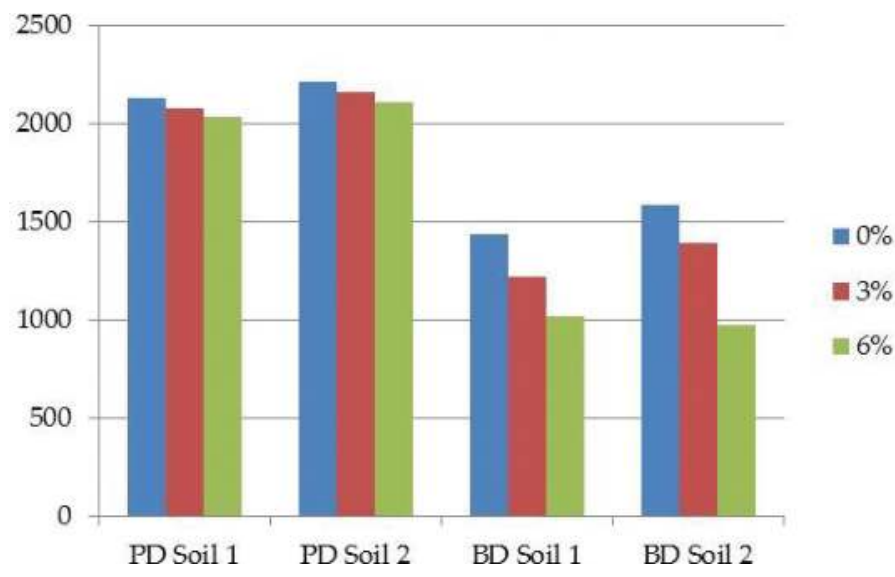

Figure 3. Particle density (PD) and bulk density (BD) (in $\mathrm{kg} / \mathrm{m}^{3}$ ) in soils amended with palm tree leaves. 
the agricultural waste, it will be more or less efficient. In this sense, straw residues reduce the bulk density more than that of palm tree leaves.

Bulk density decreases in the soils, which means that the porosity, spaces that can be filled with air and water, increases. This is observed in Figure 4, where the changes in the porosity of the two soils were showed. Porosity increased when the amount of agricultural wastes applied was greater. Hay straw residue increased the porosity more than palm tree residue.

Obviously, the types of waste that improve the porosity of soils also favor the movement of water. This fact is very important because it allows a better root growth.

One of the parameters that gives information on the movement of water in soils is the saturated hydraulic conductivity (Khs), based on Darcy's law, and calculated by using a constanthead permeameter. The texture of the soils determines the quantity and size of the pore, and, therefore, we should expect that more clay soils have lower Khs values than those with a sandy texture.

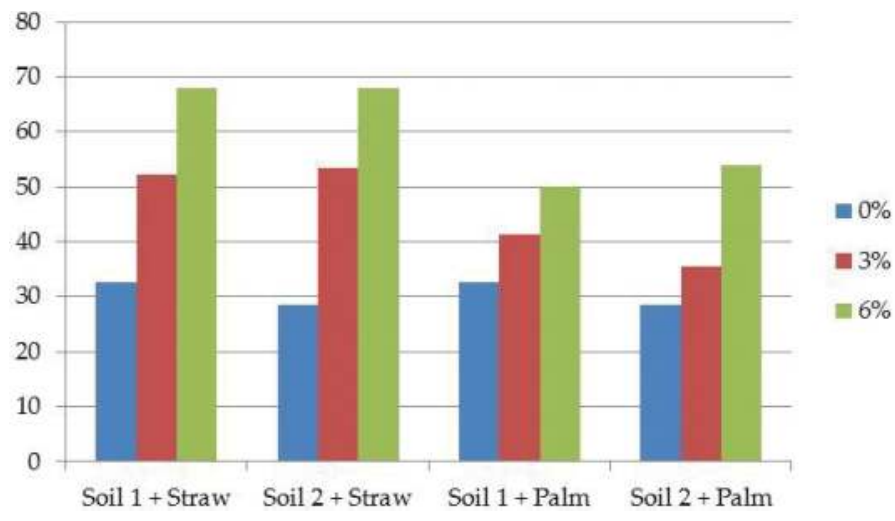

Figure 4. Porosity (\%) in soils amended with vegetable wastes.

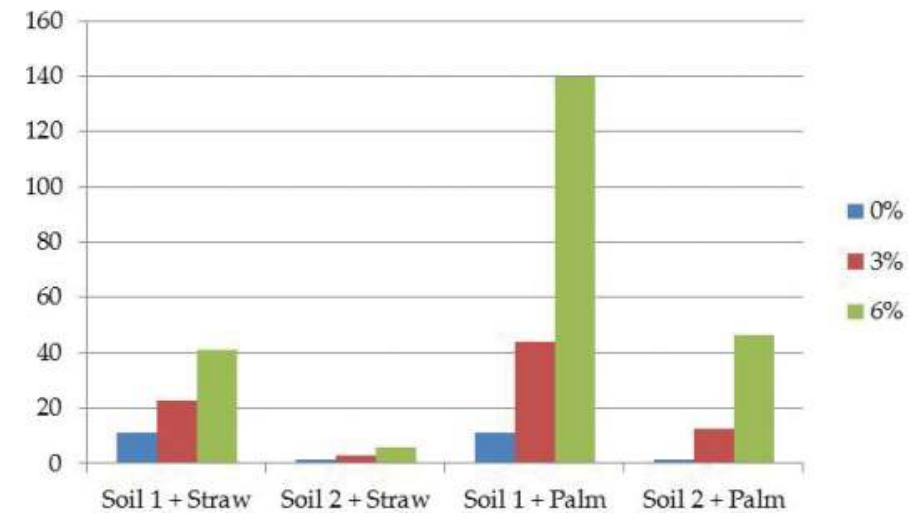

Figure 5. Saturated hydraulic conductivity (in $\mathrm{cm} / \mathrm{h}$ ) in soils amended with hay straw and palm tree leaves. 
Figure 5 shows how the addition of agricultural wastes affected the saturated hydraulic conductivity of soils. It is observed that, without the addition of residues, the clay loam soil (soil 2) has a lower value of Khs than the sandy clay loam soil (soil 1). The positive effect of the incorporation of the amendments on the hydraulic conductivity of the two soils used was clear. Hay straw produced a greater increment than palm tree residues in both soils.

This example of addition of vegetable wastes to the soil demonstrates the positive influence on some physical properties, and the importance of recycling of agricultural wastes in origin can help the strategy of zero waste of the European Union and, moreover, improve the quality of our soils.

\section{Conclusions}

It is important to consider which type of soil characteristics should be improved when applying agricultural wastes. For the physical properties, vegetable wastes with a high content of lignified organic matter can be used successfully, influencing soil density, porosity, and hydraulic conductivity. However, if the objective is to increment the nutrient availability, less lignified and more labile residues may be added to the soil, although in this case a possible imbalance of nutrients in soil may be found.

The main objective in the EU and, in fact, in the planet, is to reduce the production and increase the recycling of agricultural wastes, participating on the valorization of the residues and introducing them in the strategies of the circular economy and zero wastes. Joining soil and organic matter amendments allows us to get better soils and the best agricultural management, favoring the carbon sequestration under the present climate change scenery.

\section{Author details}

María Belén Almendro-Candel ${ }^{1}$, Ignacio Gómez Lucas $^{1 *}$, Jose Navarro-Pedreño ${ }^{1}$ and Antonis A. Zorpas ${ }^{2}$

*Address all correspondence to: ignacio.gomez@umh.es

1 Department of Agrochemistry and Environment, Miguel Hernández University of Elche, Elche (Alicante), Spain

2 Cyprus Open University, Faculty of Pure and Applied Sciences, Environmental Conservation and Management, Laboratory of Chemical Engineering and Engineering Sustainability, Nicosia, Cyprus

\section{References}

[1] European Commission. Communication from the Commission to the European Parliament, the Council, the European Economic and Social Committee and the Committee of the 
Regions. Closing the loop - An EU action plan for the Circular Economy. COM 614 final. 2015. 21 p. Available from: http://eur-lex.europa.eu/resource.html?uri=cellar:8a8ef5e8-99a011e5-b3b7-01aa75ed71a1.0012.02/DOC_1\&format=PDF [Accessed: 2018-04-21]

[2] Kong L. Maize residues, soil quality, and wheat growth in China. A review. Agronomy for Sustainable Development. 2014;34:405-416. DOI: 10.1007/s13593-013-0182-5

[3] Cotching WE. Organic matter in the agricultural soils of Tasmania, Australia - A review. Geoderma. 2018;312:170-182. DOI: 10.1016/j.geoderma.2017.10.006

[4] Marmo L. EU strategies and policies on soil and waste management to offset greenhouse gas emissions. Waste Management. 2008;28:685-689. DOI: 10.1016/j.wasman.2007.09.030

[5] Peltre C, Gregorich EG, Bruun S, Jensen LS, Magid J. 2017. Repeated application of organic waste affects soil organic matter composition: Evidence from thermal analysis, FTIR-PAS, amino sugars and lignin biomarkers. Soil Biology and Biochemistry. 2017;104:117-127. DOI: 10.1016/j.soilbio.2016.10.016

[6] Annabi M, Le Bissonnais Y, Le Villio-Poitrenaud M, Houot S. Improvement of soil aggregate stability by repeated applications of organic amendments to a cultivated silty loam soil. Agriculture, Ecosystems and Environment. 2011;144:382-389. DOI: 10.1016/j.agee.2011. 07.005

[7] Grosbellet C, Vidal-Beaudet L, Caubel V, Charpentier S. Improvement of soil structure formation by degradation of coarse organic matter. Geoderma. 2011;162(1-2):27-38. DOI: 10.1016/j.geoderma.2011.01.003

[8] Schjønning P, Thomsen IK. Shallow tillage effects on soil properties for temperate-region hard-setting soils. Soil and Tillage Research. 2013;132:12-20. DOI: 10.1016/j.still.2013.04.006

[9] Diacono M, Montemurro F. Long-term effects of organic amendments on soil fertility. A review. Agronomy for Sustainable Development. 2010;30:401-422. DOI: 10.1051/agro/200904

[10] Lal R. Soil carbon sequestration impacts on global climate change and food security. Science. 2004;304:1623-1627. DOI: 10.1126/science.1097396

[11] Celik I, Ortas I, Kilic S. Effects of compost, mycorrhiza, manure and fertilizer on some physical properties of a Chromoxerert soil. Soil and Tillage Research. 2004;78(1):59-67. DOI: 10.1016/j.still.2004.02.012

[12] Herencia JF, García-Galavís PA, Maqueda C. Long-term effect of organic and mineral fertilization on soil physical properties under greenhouse and outdoor management practices. Pedosphere. 2011;21(4):443-453. DOI: 10.1016/S1002-0160(11)60146-X

[13] Li Z, Schneider RL, Morreale SJ, Xie Y, Li C, Li J. Woody organic amendments for retaining soil water, improving soil properties and enhancing plant growth in desertified soils of Ningxia, China. Geoderma. 2018;310:143-152. DOI: 10.1016/j.geoderma.2017.09.009

[14] Martin MP, Seen DL, Boulonne L, Jolivet C, Nair KM, Bourgeon G, Arrouays D. Optimizing pedotransfer functions for estimating soil bulk density using boosted regression trees. Soil Science Society of America Journal. 2009;73:485-493. DOI: 10.2136/sssaj2007.0241 
[15] Watts CW, Clark LJ, Poulton PR, Powlson DS, Whitmore AP. The role of clay, organic carbon and long-term management on mouldboard plough draught measured on the Broadbalk wheat experiment at Rothamsted. Soil Use and Management. 2006;22:334-341. DOI: $10.1111 / j .1475-2743.2006 .00054 . x$

[16] Rico Hernández J, Navarro-Pedreño J, Gómez I. Evaluation of plant waste used as mulch on soil moisture retention. Spanish Journal of Soil Science. 2016;6(2):133-144. DOI: 10.3232/ SJSS.2016.V6.N2.05

[17] Lal R. Soil structure and sustainability. Journal of Sustainable Agriculture. 1991;1(4):67-92. DOI: 10.1300/J064v01n04_06

[18] Young IM, Blanchart E, Chenu C, Dangerfield M, Fragoso C, Grimald M, Ingram J, Monrozier LJ. The interaction of soil biota and soil structure under global change. Global Change Biology. 1998;4(7):703-712. DOI: 10.1046/j.1365-2486.1998.00194.x

[19] Allison FE, editor. Soil Organic Matter and its Role in Crop Production. 1st ed. Vol. 3. Amsterdam: Elsevier; 1973. 637 p

[20] Low AJ. Soil structure and crop yield. European Journal of Soil Science. 1973;24:249-259. DOI: 10.1111/j.1365-2389.1973.tb00762.x

[21] Rabot E, Wiesmeier M, Schlüter S, Vogel H-J. Soil structure as an indicator of soil functions: A review. Geoderma. 2018;314:122-137. DOI: 10.1016/j.geoderma.2017.11.009

[22] Snyder VA, Vázquez MA. Structure. In: Hillel D, editor. Encyclopedia of Soils in the Environment. London: Elsevier; 2005. pp. 54-68. DOI: 10.1016/B0-12-348530-4/00533-6

[23] Bronick CJ, Lal R. Soil structure and management: A review. Geoderma. 2005;124(1-2): 3-22. DOI: 10.1016/j.geoderma.2004.03.005

[24] Six J, Elliott ET, Paustian K. Soil structure and soil organic matter II. A normalized stability index and the effect of mineralogy. Soil Science Society of America Journal. 2000;64(3): 1042-1049. DOI: $10.2136 /$ sssaj2000.6431042x

[25] Gülser C. Effect of forage cropping treatments on soil structure and relationships with fractal dimensions. Geoderma. 2006;131(1-2):33-44. DOI: 10.1016/j.geoderma.2005.03.004

[26] Gülser C, Minkina T, Sushkova S, Kizilkaya R. Changes of soil hydraulic properties during the decomposition of organic waste in a coarse textured soil. Journal of Geochemical Exploration. 2017;174:66-69. DOI: 10.1016/j.gexplo.2016.05.014

[27] Chan KY, Heenan DP, So HB. Sequestration of carbon and changes in soil quality under conservation tillage on light-textured soils in Australia: A review. Australian Journal of Experimental Agriculture. 2003;43:325-334. DOI: 10.1071/EA02077

[28] Walia MK, Dick WA. Selected soil physical properties and aggregate-associated carbon and nitrogen as influenced by gypsum, crop residue, and glucose. Geoderma. 2018;320: 67-73. DOI: 10.1016/j.geoderma.2018.01.022 
[29] Hiel MP, Chélin M, Parvin N, Barbieux S, Degrune F, Lemtiri A, Colinet G, Degré A, Bodson B, Garré S. Crop residue management in arable cropping systems under temperate climate. Part 2: Soil physical properties and crop production. A review. Biotechnology, Agronomy, Society and Environment. 2016;20(S1):245-256

[30] Holland JM. The environmental consequences of adopting conservation tillage in Europe: Reviewing the evidence. Agriculture, Ecosystems and Environment. 2004;103(1):1-25. DOI: 10.1016/j.agee.2003.12.018

[31] Tisdall JM, Oades JM. Organic matter and water-stable aggregates in soils. Journal of Soil Science. 1982;33(2):141-163. DOI: 10.1111/j.1365-2389.1982.tb01755.x

[32] Six J, Elliott ET, Paustian K, Doran JW. Aggregation and soil organic matter accumulation in cultivated and native grassland soils. Soil Science Society of America Journal. 1998; 62(5):1367-1377. DOI: 10.2136/sssaj1998.03615995006200050032x

[33] Franzluebbers AJ. Water infiltration and soil structure related to organic matter and its stratification with depth. Soil and Tillage Research. 2002;66(2):197-205. DOI: 10.1016/S01 67-1987(02)00027-2

[34] Ramos MC, Nacci S, Pla I. Effect of raindrop impact and its relationship with aggregate stability to different disaggregation forces. Catena. 2003;53(4):365-376. DOI: 10.1016/S03 41-8162(03)00086-9

[35] Van den Akker JJ. Soane. B. Compaction. In: Hillel D, editor. Encyclopedia of Soils in the Environment. London: Elsevier; 2005. pp. 285-293. DOI: 10.1016/B0-12-348530-4/00248-4

[36] Barbera AC, Maucieri C, Cavallaro V, Ioppolo A, Spagna G. Effects of spreading olive mill wastewater on soil properties and crops, a review. Agricultural Water Management. 2013; 119:43-53. DOI: 10.1016/j.agwat.2012.12.009

[37] Nimmo JR. Porosity and pore size distribution. In: Hillel D, editor. Encyclopedia of Soils in the Environment. London: Elsevier; 2005. pp. 295-303. DOI: 10.1016/B0-12-348530-4/00404-5

[38] Blake GR, Hartge KH. Bulk density. In: Klute A, editor. Methods of Soil Analysis, Part 1. 2nd ed. Madison: Soil Science Society of America; 1986. pp. 363-376. DOI: 10.2136/sssa bookser5.1.2ed.c13

[39] Arshad MA, Lowery B, Grossman B. Physical tests for monitoring soil quality. In: Doran JW, Jones AJ, editors. Methods for Assessing Soil Quality, SSSA Special Publication 49. 1st ed. Madison: Soil Science Society of America; 1996. pp. 123-142. DOI: 10.2136/sssaspecpub49.c7

[40] $\mathrm{Hu}$ W, Shao MA, Si BC. Seasonal changes in surface bulk density and saturated hydraulic conductivity of natural landscapes. European Journal of Soil Science. 2012;63:820-830. DOI: 10.1111/j.1365-2389.2012.01479.x

[41] Dal Ferro N, Sartori L, Simonetti G, Berti A, Morari F. Soil macro- and microstructure as affected by different tillage systems and their effects on maize root growth. Soil and Tillage Research. 2014;140:55-65. DOI: 10.1016/j.still.2014.02.003 
[42] Connolly RD. Modelling effects of soil structure on the water balance of soil-crop systems: A review. Soil and Tillage Research. 1998;48:1-19. DOI: 10.1016/S0167-1987(98)00128-7

[43] Hillel D. Environmental Soil Physics: Fundamentals, Applications, and Environmental Considerations. 1st ed. New York: Academic Press; 1998. 771 p

[44] Moutier M, Shainberg I, Levy GJ. Hydraulic gradient and wetting rate effects on the hydraulic conductivity of two calcium Vertisols. Soil Science Society of America Journal. 2000;64:1211-1219. DOI: 10.2136/sssaj2000.6441211x

[45] West LT, Abrew MA, Bishop JP. Saturated hydraulic conductivity of soils in the southern piedmont of Georgia, USA: Field evaluation and relation to horizon and landscape properties. Catena. 2008;73:174-179. DOI: 10.1016/j.catena.2007.07.011

[46] Lim TJ, Spokas KA, Feyereisen G, Novak JM. Predicting the impact of biochar additions on soil hydraulic properties. Chemosphere. 2016;142:136-144. DOI: 10.1016/j.chemosphere.2015.06.069

[47] Keller T, Sutter JA, Nisse K, Rydberg T. Using field measurement of saturated soil hydraulic conductivity to detect low-yielding zones in three Swedish fields. Soil and Tillage Research. 2012;124:68-77. DOI: 10.1016/j.still.2012.05.002

[48] Quin PR, Cowie AL, Flavel RJ, Keen BP, Macdonald LM, Morris SG, Singh BP, Young IM, Van Zwieten L. Oil mallee biochar improves soil structural properties - A study with Xray micro-CT. Agriculture, Ecosystems and Environment. 2014;191:142-149. DOI: 10.1016/ j.agee.2014.03.022

[49] Reynolds WD, Bowman BT, Brunke RR, Drury CF, Tan CS. Comparison of tension infiltrometer, pressure infiltrometer, and soil core estimates. Soil Science Society of America Journal. 2000;64:478-484. DOI: 10.2136/sssaj2000.642478x

[50] Mwendera EJ, Feyen J. Predicting tillage effects on infiltration. Soil Science. 1993;155:229-235

[51] Hansen B, Schjønning P, Sibbesen E. Roughness indices for estimation of depression storage capacity of tilled soil surfaces. Soil and Tillage Research. 1999;52:103-111. DOI: 10.1016/ S0167-1987(99)00061-6

[52] Smika DE, Unger PW. Effect of surface residues on soil water storage. Advances in Soil Sciences. 1986;5:111-138. DOI: 10.1007/978-1-4613-8660-5_2

[53] Blevins RL, Frye WW. Conservation tillage: An ecological approach to soil management. Advances in Agronomy. 1993;51:33-78. DOI: 10.1016/S0065-2113(08)60590-8

[54] Yang X, Ikehata K, Lerner R, Hu Y, Josyula K, Chang SX, Liu Y. Agricultural Wastes. Water Environment Research. 2010;82(10):1396-1425. DOI: 10.2175/106143010X12756668801338

[55] Candemir F, Gülser C. Effects of different agricultural wastes on some soil quality indexes at clay and loamy sand fields. Communications in Soil Science and Plant Analysis. 2010; 42(1):13-28. DOI: 10.1080/00103624.2011.528489

[56] Gülser C, Candemir F. Effects of agricultural wastes on the hydraulic properties of a loamy sand cropland in Turkey. Soil Science \& Plant Nutrition. 2015;61(3):384-391. DOI: 10.1080/ 00380768.2014.992042 
[57] Singh B, Shan YH, Johnson-Beebout SE, Singh Y, Buresh RJ. Crop residue Management for Lowland Rice-Based Cropping Systems in Asia. Advances in Agronomy. 2008;98:117-199. DOI: 10.1016/S0065-2113(08)00203-4

[58] Demir Z, Gülser C. Effects of rice husk compost application on soil quality parameters in greenhouse conditions. European Journal of Soil Science. 2015;4(3):185-190. DOI: 10.183 93/ejss.2015.3.185-190

[59] Anikwe MAN. Amelioration of a heavy clay loam soil with rice husk dust and its effect on soil physical properties and maize yield. Bioresource Technology. 2000;74(2):169-173. DOI: 10.1016/S0960-8524(00)00007-9

[60] Eigenberg RA, Doran JW, Niennaber JA, Ferguson RB, Woodbury BL. Electrical conductivity monitoring of soil condition and available $\mathrm{N}$ with animal manure and a cover crop. Agriculture, Ecosystems and Environment. 2002;88(2):183-193. DOI: 10.1016/S0167-8809 (01)00256-0

[61] Turmel MS, Speratti A, Baudron F, Verhulst N, Govaerts B. Crop residue management and soil health: A systems analysis. Agricultural Systems. 2015;134:6-16. DOI: 10.1016/j.agsy. 2014.05.009

[62] Salinas-García JR, Báez-González AD, Tiscareño-López M, Rosales-Robles E. Residue removal and tillage interaction effects on soil properties under rain-fed corn production in Central Mexico. Soil and Tillage Research. 2001;59:67-79. DOI: 10.1016/S0167-1987(00)00187-2

[63] Schutter M, Sandeno J, Dick R. Seasonal, soil type, and alternative management influences on microbial communities of vegetable cropping systems. Biology and Fertility of Soils. 2001;34:397-410. DOI: 10.1007/s00374-001-0423-7

[64] Roldán A, Caravaca F, Hernández MT, García C, Sánchez-Brito C, Velásquez M, Tiscareño M. No-tillage, crop residue additions, and legume cover cropping effects on soil quality characteristics under maize in Patzcuaro watershed (Mexico). Soil and Tillage Research. 2003;72:65-73. DOI: 10.1016/S0167-1987(03)00051-5

[65] Alvarez R. A review of nitrogen fertilizer and conservation tillage effects on soil organic carbon storage. Soil Use and Management. 2005;21(1):38-52. DOI: 10.1111/j.1475-2743.2005. tb00105.x

[66] Kachroo D, Dixit AK. Residue-management practices using fly ash and various crop residues for productivity of rice (Oryza sativa)-wheat (Triticum aestivum) cropping system under limited moisture conditions. Indian Journal of Agronomy. 2005;50(4):249-252

[67] Blanco-Canqui H, Lal R. Corn Stover removal for expanded uses reduces soil fertility and structural stability. Soil Science Society of America Journal. 2009;73:418-426. DOI: 10.2136/ sssaj2008.0141

[68] Ludwig B, Geisseler D, Michel K, Joergensen RG, Schulz E, Merbach I, Raupp J, Rauber R, $\mathrm{Hu}$ K, Niu L, Liu X. Effects of fertilization and soil management on crop yields and carbon stabilization in soils. A review. Agronomy for Sustainable Development. 2011;31:361-372. DOI: 10.1051/agro/2010030 
[69] Agneessens L, De Waele J, De Neve S. Review of alternative management options of vegetable crop residues to reduce nitrate leaching in intensive vegetable rotations. Agronomy. 2014;4:529-555. DOI: 10.3390/agronomy4040529

[70] Hardie MA, Cotching WE. Effects of application of poppy waste on spinach yields, soil properties, and soil carbon sequestration in southern Tasmania. Australian Journal of Soil Research. 2009;47(5):478-485. DOI: 10.1071/SR08193

[71] Dundar A, Yildiz A. A comparative study on Pleurotus ostreatus (Jacq.) P. Kumm. Cultivated on different agricultural Lignocellulosic wastes. Turkish Journal of Biology. 2009; 33(2):171-179. DOI: 10.3906/biy-0804-2

[72] Temporal-Lara B, Melendez-Pastor I, Gómez I, Navarro-Pedreño J. Wastewater biosolid composting optimization based on UV-VNIR spectroscopy monitoring. Sensors. 2016;16: 1-11. DOI: $10.3390 / \mathrm{s} 16111919$

[73] Khan GD, Din S, Ramzan M, Hanif M, Hameed M. Influence of tillage and mulching practices on soil physical properties under semi-arid environment. Journal of Environment and Earth Science. 2014;4(9):120-124

[74] Melgar R, Benítez E, Nogales R. Bioconversion of wastes from olive oil industries by vermicomposting process using the Epigeic earthworm Eisenia andrei. Journal of Environmental Science and Health, Part B - Pesticides, Food Contaminants, and Agricultural Wastes. 2009;44(5):488-495. DOI: 10.1080/03601230902935444

[75] Medina J, Monreal C, Barea JM, Arriagada C, Borie F, Cornejo P. Crop residue stabilization and application to agricultural and degraded soils: A review. Waste Management. 2015;42:41-54. DOI: 10.1016/j.wasman.2015.04.002

[76] Austin AT, Ballaré CL. Dual role of lignin in plant litter decomposition in terrestrial ecosystems. Proceedings of the National Academy of Sciences of the United States of America. 2010;107(10):4618-4622. DOI: 10.1073/pnas.0909396107

[77] European Commission. Guidelines on Best Practice to Limit, Mitigate or Compensate Soil Sealing. European Commission Staff Working Document SWD(2012) Report 101 Final/2. Luxembourg: Publications Office or the European Union; 2012. 62 p. DOI: 10.2779/75498

[78] Manzoni S, Trofymow JA, Jackson RB, Porporato A. Stoichiometric controls on carbon, nitrogen, and phosphorus dynamics in decomposing litter. Ecological Monographs. 2010; 80:89-106. DOI: 10.1890/09-0179.1

[79] Navarro-Pedreño J, Moral R, Gómez I, Mataix J. Residuos Orgánicos en Agricultura. Ed. Servicio Publicaciones de la Universidad de Alicante; 1995. 155 p

[80] Cao C, Liu SQ, Ma ZB, Lin Y, Su Q, Chen H, Wang JJ. Dynamics of multiple elements in fast decomposing vegetable residues. The Science of the Total Environment. 2018;616-617: 614-621. DOI: 10.1016/j.scitotenv.2017.10.287 
[81] Klotzbücher T, Kaiser K, Guggenberger G, Gatzek C, Kalbitz K. A new conceptual model for the fate of lignin in decomposing plant litter. Ecology. 2011;92:1052-1062. DOI: 10.1890/ 10-1307.1

[82] Blake GR, Hartge KH. Bulk density. In: Klute A, editor. Methods of Soil Analysis: Part 1Physical and Mineralogical Methods. Madison: SSSA, ASA. 1986. pp. 363-375. DOI: 10.2136/ sssabookser5.1.2ed.c13

[83] Blake GR, Hartge KH. Particle density. In: Klute A, editor. Methods of Soil Analysis: Part 1 -Physical and Mineralogical Methods. Madison: SSSA, ASA; 1986. pp. 377-382. DOI: 10.21 36/sssabookser5.1.2ed.c14

[84] Danielson RE, Sutherland PL. Porosity. In: Klute A, editor. Methods of Soil Analysis: Part 1 -Physical and Mineralogical Methods. Madison: SSSA, ASA; 1986. pp. 443-461. DOI: 10.21 36/sssabookser5.1.2ed.c18 
